\title{
Barriers of Mobile Commerce Adoption Intention: Perceptions of Generation X in Malaysia
}

\section{Krishna Moorthy ${ }^{1}$, Ching Suet Ling ${ }^{2}$, Yeong Weng Fatt ${ }^{3}$, Chan Mun Yee ${ }^{4}$, Elaine Chong Ket Yin ${ }^{5}$, Kwa Sin Yee ${ }^{6}$ and Lee Kok Wei ${ }^{7}$}

\footnotetext{
${ }^{1}$ Universiti Tunku Abdul Rahman, Kampar Campus, Perak State, Malaysia, krishnam@utar.edu.my

2 Universiti Tunku Abdul Rahman, Kampar Campus, Perak State, Malaysia, chingsl@utar.edu.my

${ }^{3}$ Universiti Tunku Abdul Rahman, Kampar Campus, Perak State, Malaysia, yeongwf@1utar.my

${ }^{4}$ Universiti Tunku Abdul Rahman, Kampar Campus, Perak State, Malaysia, 93chanmunyee@1utar.my

${ }^{5}$ Universiti Tunku Abdul Rahman, Kampar Campus, Perak State, Malaysia, elainecky@1utar.my

${ }^{6}$ Universiti Tunku Abdul Rahman, Kampar Campus, Perak State, Malaysia, kwa07170@1utar.my

7 Universiti Tunku Abdul Rahman, Kampar Campus, Perak State, Malaysia, kokweilee93@1utar.my
}

Received 12 April 2016; received in revised form 3 November 2016; accepted 15 December 2016

\section{Abstract}

Many telecommunication companies in Malaysia have been attracted to invest significantly in the development of mobile commerce due to the explosive growth in the usage and market penetration of mobile devices. Eventhough generation $X$ is characterized with high earning power, as they are reluctant on technological advancements, the mobile commerce adoption rate is remaining low in Malaysia. Therefore, this study is intended to explore the resistance factors to understand the reasons for this low adoption among generation X in Malaysia. Innovation Resistance Theory (IRT) and Valence Framework have been employed to examine the barriers, including usage, value, risk, tradition, image, and perceived cost barriers. The results of this study have been derived from data collected from 227 generation $X$ consumers through questionnaire survey. The findings of this study show that, except the cost barrier, all other barriers significantly affect the mobile commerce adoption. These results enable local businesses to develop solutions to eliminate the resistance barriers and act as a means of understanding how to possibly enhance the rate of mobile commerce adoption in Malaysia. This research provides an extended Innovation Resistance Theory model by adding the perceived cost barrier construct, a negative valence factor, for the adoption intention of mobile commerce.

Keywords: Mobile commerce, Innovation resistance theory, Negative valence factor, Generation X, Malaysia. 


\section{Introduction}

Nowadays, mobile commerce (MC) has become more popular due to the explosive growth in the usage and market penetration of mobile devices. Mobile commerce is the performance of transactions using mobile devices. Mobile commerce includes mobile ticketing, mobile banking, mobile marketing, mobile information services, mobile shopping, mobile entertainment and many more. In Malaysia, $86.3 \%$ of the citizens are mobile phone users (Malaysian Communications and Multimedia Commission, 2013). Generation X refers to people who were born between 1960 and 1980. They are non-materialistic, have high earning power, reluctant on brand name and technological advancements. They constitute $23.9 \%$ of the total population in Malaysia [9]. Hence, generation $\mathrm{X}$ is one of the popular targeted segments due to their predominant population and purchasing power. Hence, it is important to apprehend the intention of generation $\mathrm{X}$ in mobile commerce adoption.

\section{Research Gap}

The number of Internet users in Malaysia has been overtaken by the number of mobile phone subscribers. Mobile commerce has attracted considerable traffic and many telecommunication companies after realizing its potentials, have invested considerably in developing this. Consequently, business environments have been motivated by this innovation to establish efficient and effective ways of operating businesses. Nevertheless, Digital Malaysia [10] had reported that the total amount spent on mobile commerce (RM467 million) is only a quarter of electronic commerce (RM 1.78 billion). The percentage of individuals using mobile phone and computer are $94.2 \%$ and $56 \%$, respectively [9]. This shows that the mobile phone has a higher penetration rate but a lower amount has been spent in mobile commerce compared to electronic commerce. Thus, the above comparison indicates that it is necessary to further explore the causal factors in the resistance of mobile commerce adoption intention in Malaysia.

Malaysia is considered one of the fastest growing countries worldwide in terms of mobile phone with a penetration rate of $146.2 \%$ [29]. Hence, the telecommunication companies should understand the reasons for the low adoption of mobile commerce. Numerous studies, including Peng, Xu, and Liu [34], Mahatanankoon and Vila-Ruiz [28], and Rahman [36] had addressed similar problems. All these studies were intended to find out the adoption barriers of mobile commerce in respective countries to act as a reference for the telecommunication companies to develop a solution for this problem. Peng, Xu and Liu [34] determined the barriers and drivers in the acceptance of mobile commerce in China; Mahatanankoon and Vila-Ruiz [28] investigated possible barriers that obstruct the adoption of mobile commerce applications; and Rahman [36] examined the resistance factors of mobile commerce adoption in developing countries, and ways to overcome these barriers.

However, the study done by Peng, $\mathrm{Xu}$ and Liu [34] is aimed to investigate only two adoption barriers of mobile commerce in China. The research done by Rahman [36] was targeted on the stakeholders of mobile commerce and the target respondents of this study are generation $X$ consumers, whereby the telecommunication companies would prefer to know the resistance barriers from the consumers' perspective. Mahatanankoon and Vila-Ruiz [28] had conducted the research to determine the adoption barriers of mobile commerce in the US. This study is intended to explore the resistance factors to understand the reasons for the low adoption rate of mobile commerce among generation $\mathrm{X}$ in Malaysia.

\section{Objectives and Significance of the Study}

This study is intended to explore the resistance factors to understand the reasons for the low adoption rate of mobile commerce among generation $X$ in Malaysia. The main objective of this study is to determine the relationship between usage barrier, value barrier, risk barrier, tradition barrier, image barrier and perceived cost barrier and mobile commerce adoption intention among generation $\mathrm{X}$ in Malaysia. Another objective of this study is to examine the statistical differences in the mobile commerce adoption intention between the mobile commerce users and nonusers of Generation X in Malaysia. Innovation Resistance Theory (IRT) and a negative valence factor have been employed to examine the barriers.

Although many past studies had attempted to investigate the use of mobile commerce, there is a need to understand the reasons why customers resist the innovation rather than adopt it, since customers' resistance is a significant cause of market failure for innovations [6]. Therefore, the barriers to mobile commerce adoption are vital information for the local businesses which intend or currently adopt the use of mobile commerce in order to improve its adoption rate. The findings of this study would enable local businesses to have a better understanding of the relationship between all barriers and the consumers' adoption intention of mobile commerce in Malaysia. Thus, this study would contribute to the understanding of individual resistance behavior and assists local business to develop solutions to eliminate the resistance and possibly enhance the adoption rate.

As mobile commerce is becoming indispensable in Malaysia, resistance factors in mobile commerce adoption are the critical information to increase its adoption rate. Generation X is considered to have a large purchasing power with a major market segment in the mobile commerce industry. This study intends to further investigate the major 
barriers to mobile commerce adoption by adapting all five elements of Innovation Resistance Theory and an additional factor, perceived cost barrier which has been frequently reported as a significant barrier to innovation adoption [47]. Although there are many studies that present mobile commerce literature, few have integrated the Innovation Resistance Theory model. As such, future researchers who are interested in studying the similar issue could use the findings of this study as reference.

\section{Literature Review}

The model applied in this research is Innovation Resistance Theory (IRT) which is developed by Ram and Sheth [37] Innovation resistance is generally a reaction result from a sensible choice and it is the resistance faced by consumers to innovation, due to the probable deviations from an adequate status quo or because it clashes with their belief structure. The need to study the innovation resistance is due to a very high rate of new product failure encountered by most of the businesses. Thus, Ram and Sheth [37] have developed this theory to explain why customers resist innovations.

All five concepts from Innovation resistance Theory would be adapted, specifically usage, value, risk, tradition and image barriers and another perceived cost barrier (PCB) a negative valence factor, as independent variables to examine the barriers towards adopting mobile commerce among Gen X in Malaysia. Perceived cost barrier is added since several studies suggest that perceived cost is a barrier against the adoption of new technologies, including those related to mobile service [26]. This result is consistent with the research done by Wei, Marthandan, Chong, Ooi, and Arumugam [45], which identified that the perceived cost has negative impact to the adoption of mobile commerce among the consumers. Hence, perceived cost barrier is an appropriate factor to examine the barriers of the adoption of mobile commerce.

The definition and sources of the variables are listed below in Table 1.

Table 1: Definition and sources of variables

\begin{tabular}{|c|c|c|}
\hline Variables & Definition & Sources \\
\hline Usage barrier & $\begin{array}{l}\text { Resistance towards a new invention due to } \\
\text { the inconsistence with current routine, } \\
\text { exercise, and plan. }\end{array}$ & Barati and Mohammadi [4] \\
\hline Value barrier & $\begin{array}{l}\text { Resistance towards the usage of products or } \\
\text { services when they do not fulfill user's } \\
\text { perception of performance-to-price value in } \\
\text { contrast with other substitutes. }\end{array}$ & Rammile and Nel [39] \\
\hline Risk barrier & $\begin{array}{l}\text { Uncertainty regarding possible negative } \\
\text { consequences of using a product or service. }\end{array}$ & $\begin{array}{l}\text { Marett, Pearson, Pearson, and } \\
\text { Bergiel [30] }\end{array}$ \\
\hline Tradition barrier & $\begin{array}{l}\text { Obstacles originate when a technology } \\
\text { innovation poses a change in customer's } \\
\text { established tradition. }\end{array}$ & Mohtar, Abbas, and Baig [32] \\
\hline Image barrier & $\begin{array}{l}\text { Negative thoughts of individuals toward } \\
\text { technology tools and perceived complication } \\
\text { of use. }\end{array}$ & Claudy [7] \\
\hline Perceived cost barrier & $\begin{array}{l}\text { Additional expenses that incurred in } \\
\text { transferring from wired internet payment } \\
\text { services to ubiquitous mobile payment } \\
\text { options }\end{array}$ & Lu, Yang, Chau, and Cao [25] \\
\hline Adoption intention & $\begin{array}{l}\text { Consequences of the sum of the variables } \\
\text { that culminate into an intention that } \\
\text { demonstrates that the consumer is willing to } \\
\text { perform certain actions }\end{array}$ & Joubert and Belle [16] \\
\hline
\end{tabular}

\subsection{Adoption Intention}

Adoption intention refers to the consequences of the sum of the variables that culminate into an intention demonstrating that the consumer is willing to perform certain actions [16]. Yu and Li [48] have conducted an analysis regarding the consumer resistance to adopt mobile banking in Thailand and Taiwan. Online questionnaire surveys were distributed to mobile commerce users and a total of 1,861 valid responses were gathered in these two countries. Partial Least Square has been employed to examine data obtained and the result showed that all the barriers in Innovation Resistance Theory have a negative relationship with the adoption intention of mobile commerce. M-commerce previous experience has a positive influence on future $\mathrm{M}$-commerce intention [5]. In addition, an empirical study was conducted by Laukkanen and Kiviniemi [19] to investigate how information influences Innovation Resistance Theory barriers of mobile banking in Finland. 1,551 valid samples were collected 
from the bank customers and structural equation modeling had been used to assess the hypotheses. The finding indicated that information has a significant effect on the Innovation Resistance Theory barriers which in turn negatively affected the adoption intention to mobile banking. In short, the findings of these past studies are consistent with the hypotheses of this study whereby usage, value, risk, tradition, image and perceived cost barriers have a negative relationship with the adoption intention of mobile commerce.

\subsection{Usage Barrier}

Usage barrier is defined as the resistance towards a new invention due to the inconsistency with current routine and plan [4]. A study done by Rahman [36] about deficiency in proficiency affecting the adoption of m-commerce stated that inability to read and write will restrict the adoption. In this study interviews were conducted on 27 stakeholders in Bangladesh and the result indicated that deficiency in proficiency negatively affected the adoption of $\mathrm{m}$-commerce. Qualitative content analysis was selected to analyze the interview transcript. Besides, Mahatanankoon and Vila-Ruiz [28] found out that the inefficiency of device affects the adoption of m-commerce. Incompetency of mobile device will affect the usage. Web-based survey of 215 university students was collected in the United States. Factor analysis determined that a negative relationship existed between device inefficiency and mobile commerce usage behaviors. Deficiency in the proficiency and incompetency of mobile device is related to usage barriers and they negatively affect $\mathrm{m}$-commerce adoption. Thus, the above studies support our first hypothesis that usage barrier negatively affects m-commerce adoption.

H1: There is a negative relationship between usage barrier and adoption of mobile commerce among generation $X$ in Malaysia.

\subsection{Value Barrier}

Value barrier is a resistance towards the usage of products or services when they do not fulfil user's perception of performance-to-price value, in contrast with other substitutes [39]. Aslam, Khan, Tanveer, and Amber [2] have conducted a quantitative research in Pakistan on low perceived value affecting adoption towards internet banking. In this study, structured questionnaire with 520 responses were collected from 10 banks and analyzed by SPSS for descriptive statistics. It showed that the low perceived value has negatively affected adoption intention of internet banking. In addition, Agwu [1] carried out a quantitative research on value barrier which negatively influenced the internet banking adoption. 630 usable survey questionnaires from individuals in the United Kingdom were obtained and the results showed that these two variables have a negative relationship. Hence, the hypothesis for this study is formed as follows:

H2: There is a negative relationship between value barrier and adoption of mobile commerce among generation $X$ in Malaysia.

\subsection{Risk Barrier}

Risk barriers are the uncertainties which are inherent and entail innovations [30]. The study done by LiébanaCabanillas, Sánchez-Fernández, and Muñoz-Leiva [23] is about the antecedents of the adoption of the new mobile payment systems. An online survey was conducted. 2,012 valid questionnaires were collected and the result was analyzed by using SEM. The results showed that perceived risk was negatively related to the adoption intention. Another quantitative study done by Munusamy, Annamalah, and Chelliah [33] measured the impact of innovation resistance among bank customers in Malaysia. The result was obtained by using a questionnaire-based survey of those selected banks in Malaysia and multiple regression analysis was used. Based on the result, it was concluded that perceived risk has negatively affected adoption of online banking in Malaysia.

H3: There is a negative relationship between risk barrier and adoption of mobile commerce among generation $X$ in Malaysia.

\subsection{Tradition Barrier}

Tradition barriers refers to the obstacles originate when a technology innovation poses a change in customer's established tradition [32]. A study conducted by Gutner [14] examined different forms of resistance in the context of mobile applications and used SEM for analysis. Based on the survey done on 752 Smartphone users in Germany, it showed that tradition barrier has given a negative impact on the adoption intention towards mobile applications. Another research was conducted by Lian and Yen [22] on the effect of tradition barrier on M-shopping intention in the cosmetic industry. In this study the survey questionnaires from 178 Small and Medium Enterprises (SMEs) in Taiwan were tested by multiple linear regression analysis and it has been found that there was a negative relationship of tradition barrier on M-shopping intention.

H4: There is a negative relationship between tradition barrier and adoption of mobile commerce among generation $X$ in Malaysia. 


\subsection{Image Barrier}

Image barrier is negative thoughts of individuals towards the technology tools and perceived complication of use [11]. Bakhit [3] had conducted a quantitative study to determine the resistance of the consumer towards innovations. The survey questionnaire was distributed to 50 households in North Lebanon and MLR analysis has been employed to examine the hypotheses. The result signified that image barrier has a moderate effect to resistance. Secondly, Kuisma, Laukkanen, and Hiltunen [18] had conducted a research to identify factors behind resistance towards online banking in Finland. 30 bank customers were interviewed using the means-end approach and the laddering interviewing technique. Results showed that perceived image barrier has a negative relationship with the adoption of innovation.

H5: There is a negative relationship between image barrier and adoption of mobile commerce among generation $X$ in Malaysia.

\subsection{Perceived Cost Barrier}

Perceived cost barrier refers to additional expenses that are incurred in moving from wired online payment services to mobile payment services [25]. An empirical study had been done by Pham and Ho [35] to examine the resistance of consumers to adopt mobile payments in Taiwan. The targeted respondents of this research were the mobile payment users and 402 valid surveys were collected from the web-based survey. Based on the results conducted by structural modelling analysis, it has been concluded that perceived cost barrier has an adverse effect towards the mobile payment adoption. In addition, Lu, Yang, Chau, and Cao [25] had conducted a web-based survey and collected 961 valid responses from the users of Alipay which offers mobile payment services. The hypotheses were tested using PLS. This research investigated how the consumers' adoption intention of mobile payment services was affected by positive and negative valence factors. The results specified that perceived cost barrier negatively affected students' adoption intention of mobile payment services, but had little significant impact on workers.

H6: There is a negative relationship between perceived cost barrier and adoption of mobile commerce among generation $X$ in Malaysia.

Based on the above discussions the research model of this study is given in Figure 1.

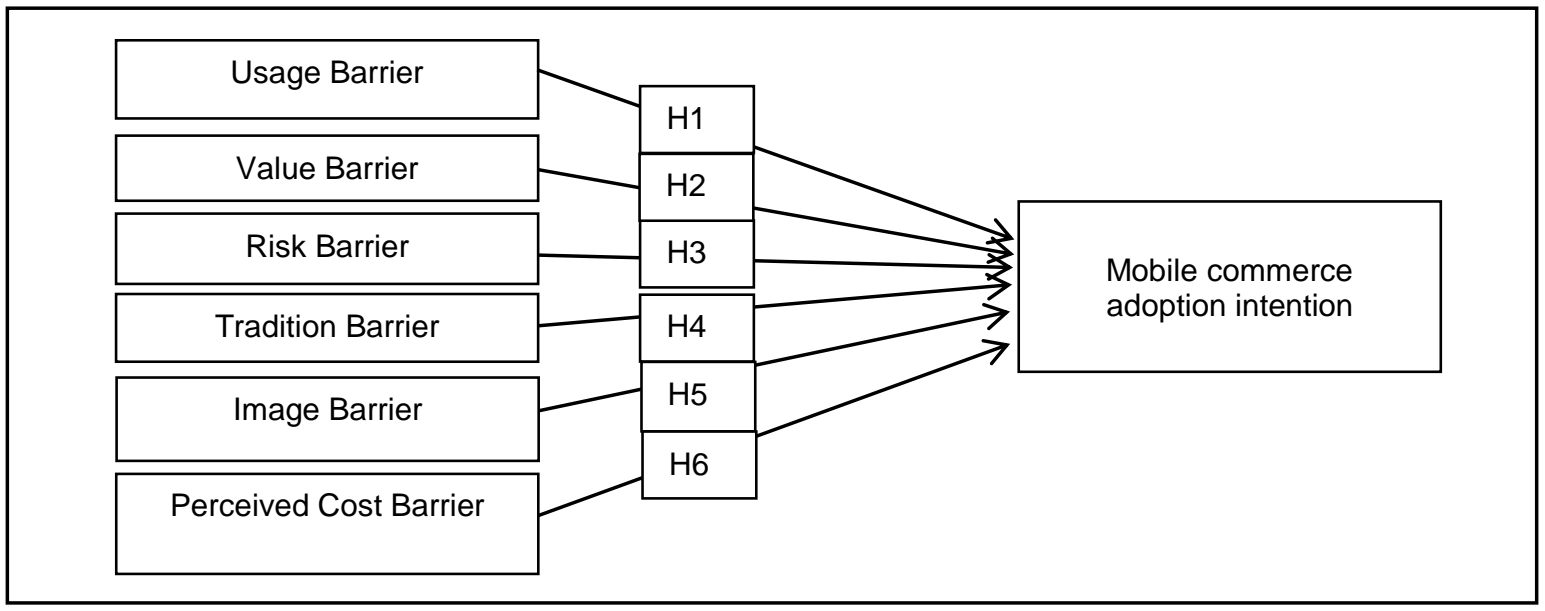

Figure 1: Research model

\section{Research Methodology}

The target population of this study is generation X in Malaysia, especially those from Selangor (Kuala Lumpur) and Negeri Sembilan States. According to MCMC (2014), 30.1\% of mobile phone users are generation X. These two States have been chosen due to their highest penetration rate of $153.3 \%$ and $156.1 \%$ mobile phone usage [29]. This research is aimed to explore the barriers to mobile commerce adoption among generation $X$ in Malaysia. Hence the unit of analysis for this study is generation X in Malaysia. Self-administrated questionnaires (Appendix A) have been distributed to target respondents, generation $X$ in these two States. This is a quantitative study as it is measurable and quantifiable by using numerical data gathered through questionnaire survey. Besides, this is a cross-sectional research as it focuses on the barriers to mobile commerce adoption among generation $\mathrm{X}$ in Malaysia for a certain period and it is only an incident to be studied at a single point in a moment. 
The convenience sampling method has been followed to conduct the survey since the sampling frame is unknown due to inability to obtain the list of generation $X$ in the above two States. Totally 400 questionnaires were distributed and 227 fully completed questionnaires were collected back. Since the goal of convenience sampling is easy access, participants were simply chosen from places near mobile phone stores. The questionnaires were prepared in English language and distributed to the target respondents by using the self-delivery method. Direct method was used for collecting data back from respondents. The survey was conducted from 10 May 2015 to 24 May 2015.

There are 26 items for the six barriers and 6 items for adoption intention to investigate in order to establish the relationship between the independent variables and the dependent variable. The items were adapted from preceding researches and were modified in this research to fit the context of Innovation Resistance Theory. 5-point Likert scales were adopted in this study which was ranged from (1) Strongly agree to (5) Strongly disagree.

\section{Results}

Demographic profile of the respondents is presented in Table 2.

Table 2: Demographic profile of respondents

\begin{tabular}{|l|l|l|}
\hline Demographic Profile & Variables & Percentage \\
\hline \multirow{4}{*}{ Gender } & Male & $46.26 \%$ \\
\cline { 2 - 3 } & Female & $53.74 \%$ \\
\hline \multirow{4}{*}{ Marital Status } & $35-39$ & $16.74 \%$ \\
\cline { 2 - 3 } & $40-44$ & $24.67 \%$ \\
\cline { 2 - 3 } & $45-49$ & $26.87 \%$ \\
\cline { 2 - 3 } & $50-55$ & $31.72 \%$ \\
\hline \multirow{4}{*}{ Education Level } & Married & $83.26 \%$ \\
\cline { 2 - 3 } & Single & $16.74 \%$ \\
\hline \multirow{4}{*}{ Race } & High School & $56.39 \%$ \\
\cline { 2 - 3 } & Degree & $29.96 \%$ \\
\cline { 2 - 3 } & Diploma & $11.89 \%$ \\
\cline { 2 - 3 } & Master & $1.76 \%$ \\
\hline \multirow{4}{*}{ Monthly Income } & Chinese & $59.03 \%$ \\
\cline { 2 - 3 } & Malay & $24.67 \%$ \\
\cline { 2 - 3 } & Indian & $16.30 \%$ \\
\hline \multirow{2}{*}{ User or Non-User of MC } & RM1,000 or below & $14.10 \%$ \\
\cline { 2 - 3 } & RM1,001 - RM3,000 & $44.93 \%$ \\
\cline { 2 - 3 } & RM3,001 - RM5,000 & $29.52 \%$ \\
\cline { 2 - 3 } & Above RM5,000 & $11.45 \%$ \\
\cline { 2 - 3 } & User & $35.32 \%$ \\
\cline { 2 - 3 } & Non-User & $3.68 \%$ \\
\hline
\end{tabular}

The normality statistics and central tendencies measurement of constructs are given in Table 3 .

Table 3: Normality statistics and central tendencies measurement of constructs

\begin{tabular}{|c|c|c|c|c|c|}
\hline Variables & Items & Skewness & Kurtosis & Means & $\begin{array}{l}\text { Standard } \\
\text { Deviation }\end{array}$ \\
\hline \multirow[t]{4}{*}{ Usage Barrier } & UB1 & 1.19112086 & 1.43435573 & 2.01322 & 0.96615 \\
\hline & UB2 & 1.05079898 & 0.66237980 & 2.15859 & 1.07730 \\
\hline & UB3 & 1.09810816 & 0.78125241 & 2.14537 & 1.06056 \\
\hline & UB4 & 1.20737491 & 1.00390030 & 2.10132 & 1.09437 \\
\hline \multirow{5}{*}{ Value Barrier } & VB1 & 1.24440962 & 1.38684812 & 2.00881 & 0.95469 \\
\hline & VB2 & 1.42662278 & 2.03380375 & 2.07930 & 0.95141 \\
\hline & VB3 & 1.48618147 & 1.93262880 & 1.96476 & 1.02560 \\
\hline & VB4 & 1.50594305 & 2.15759736 & 2.00664 & 0.98664 \\
\hline & VB5 & 1.45334740 & 1.91170299 & 1.96916 & 1.01925 \\
\hline \multirow[t]{5}{*}{ Risk Barrier } & RB1 & 1.02592035 & 1.052512257 & 2.09692 & 1.02592 \\
\hline & RB2 & 1.29123325 & 1.29222635 & 2.05727 & 1.03960 \\
\hline & RB3 & 1.18694438 & 1.10455997 & 2.12335 & 1.01438 \\
\hline & RB4 & 1.0526164 & 0.92851982 & 2.16300 & 0.98881 \\
\hline & RB5 & 0.73407405 & 0.13931201 & 2.15419 & 0.99023 \\
\hline \multirow[t]{4}{*}{ Tradition Barrier } & TB1 & 1.16076786 & 1.29967275 & 2.20264 & 0.96551 \\
\hline & TB2 & 1.17872697 & 1.45851847 & 2.26872 & 0.81090 \\
\hline & TB3 & 1.09052419 & 1.04978894 & 2.29075 & 0.83827 \\
\hline & TB4 & 1.04015527 & 1.08437662 & 2.26872 & 0.92317 \\
\hline \multirow[t]{3}{*}{ Image Barrier } & IB1 & 1.16085121 & 1.10340628 & 2.16300 & 0.97074 \\
\hline & IB2 & 1.33402557 & 1.82641443 & 2.16740 & 0.91603 \\
\hline & IB3 & 1.23876021 & 1.25573766 & 2.12775 & 0.97603 \\
\hline
\end{tabular}




\begin{tabular}{|l|l|l|l|l|l|}
\hline \multicolumn{6}{|l|}{ Table 3: continuation } \\
\hline \multirow{4}{*}{$\begin{array}{l}\text { Perceived Cost } \\
\text { Barrier }\end{array}$} & PCB1 & 0.42556175 & 0.00376459 & 2.51542 & 0.74873 \\
\cline { 2 - 6 } & PCB2 & 0.93631967 & 0.36546209 & 2.39648 & 0.67940 \\
\cline { 2 - 6 } & PCB3 & 0.95876223 & 0.36387895 & 2.42731 & 0.75712 \\
\cline { 2 - 6 } & PCB4 & 0.83057105 & 0.50933384 & 2.40969 & 0.73140 \\
\cline { 2 - 6 } & PCB5 & 0.88181705 & 0.9249299 & 2.42291 & 0.76829 \\
\hline \multirow{4}{*}{$\begin{array}{l}\text { Intoption } \\
\text { Al1 }\end{array}$} & Al2 & -1.3827097 & 1.43627723 & 4.00881 & 1.05592 \\
\cline { 2 - 6 } & Al3 & -0.9134454 & 0.35620316 & 3.83700 & 1.05799 \\
\cline { 2 - 6 } & Al4 & -1.2941679 & 1.42733288 & 3.92952 & 1.03238 \\
\cline { 2 - 6 } & Al5 & -1.0873876 & 0.80417407 & 3.84141 & 1.02683 \\
\cline { 2 - 6 } & Al6 & -1.3129838 & 1.28738725 & 3.96035 & 1.04890 \\
\hline
\end{tabular}

It can be seen in Table 3 that the means of all the independent variables are more towards agreed which ranged from 1.96476 to 2.51542, whereas the means of the dependent variable are more towards disagreed which ranged from 3.83700 to 4.00881 . The standard deviations represent the dispersion of data for all the variables. The lowest standard deviation is 0.67940 while the highest is 1.09437 . This study had employed Skewness and Kurtosis test to verify the existence of normal distribution. The endogenous variables normality is satisfactory if the value of skewness is between \pm 2 and kurtosis value is between \pm 7 [15]. As shown in Table 3, skewness values range from 1.3827097 to 1.50594305 while the kurtosis values range between 0.00376459 and 2.15759736. The absolute value of skewness is less than 2 and the absolute value of kurtosis is less than 7 . Therefore, the assumptions of normality are fulfilled.

Table 4 depicts the summary of reliability analysis.

Table 4: Summary of reliability analysis

\begin{tabular}{|l|l|l|}
\hline Variables & Number of Items & Cronbach's Alpha \\
\hline Usage Barrier & 4 & 0.888357 \\
\hline Value Barrier & 5 & 0.891432 \\
\hline Risk Barrier & 5 & 0.887608 \\
\hline Tradition Barrier & 4 & 0.867624 \\
\hline Image Barrier & 3 & 0.885742 \\
\hline Perceived Cost Barrier & 5 & 0.833619 \\
\hline Adoption Intention & 6 & 0.809832 \\
\hline
\end{tabular}

Variables are considered reliable if the Cronbach's alphas are at least 0.7 [8], [44]. Table 4 shows a minimum alpha of 0.809832 and a maximum alpha of 0.891432 . Hence all the items adapted in the questionnaire for this research can be concluded as reliable.

The Pearson correlation analysis is given in Table 5.

Table 5: Pearson correlation analysis

\begin{tabular}{|c|c|c|c|c|c|c|c|}
\hline Variables & UB & VB & RB & TB & IB & PCB & Al \\
\hline \multirow[t]{2}{*}{ UB } & 1.0000 & & & & & & \\
\hline & $<.0001$ & & & & & & \\
\hline \multirow[t]{2}{*}{ VB } & 0.75636 & 1.0000 & & & & & \\
\hline & $<.0001$ & $<.0001$ & & & & & \\
\hline \multirow[t]{2}{*}{$\mathrm{RB}$} & 0.83622 & 0.86700 & 1.0000 & & & & \\
\hline & $<.0001$ & $<.0001$ & $<.0001$ & & & & \\
\hline \multirow[t]{2}{*}{ TB } & 0.84734 & 0.83408 & 0.87899 & 1.0000 & & & \\
\hline & $<.0001$ & $<.0001$ & $<.0001$ & $<.0001$ & & & \\
\hline \multirow[t]{2}{*}{ IB } & 0.81468 & 0.79958 & 0.86894 & 0.85017 & 1.0000 & & \\
\hline & $<.0001$ & $<.0001$ & $<.0001$ & $<.0001$ & $<.0001$ & & \\
\hline \multirow[t]{2}{*}{ PCB } & 0.78116 & 0.82285 & 0.85018 & 0.85690 & 0.82317 & 1.0000 & \\
\hline & $<.0001$ & $<.0001$ & $<.0001$ & $<.0001$ & $<.0001$ & $<.0001$ & \\
\hline \multirow[t]{2}{*}{$\mathrm{Al}$} & -0.82757 & -0.83453 & -0.87639 & -0.88820 & -0.85653 & -0.82387 & 1.0000 \\
\hline & $<.0001$ & $<.0001$ & $<.0001$ & $<.0001$ & $<<.0001$ & $<.0001$ & $<.0001$ \\
\hline
\end{tabular}

The correlation values in this study are in the range of 0.75636 to 0.87899 between the independent variables which signify a positive correlation. Conversely, the dependent variable has a negative relationship with all the independent variables and ranged from -0.82387 to -0.88820 . As a result, no multicollinearity problem was revealed since none of the correlation values have higher than 0.90 coefficient in this research [12]. Moreover, it shows that the variables have $p$-values that are less than 0.05 [24]. Hence, there are significant relationships between the variables. 
The model summary is given in Table 6 .

Table 6: Summary of Model

\begin{tabular}{|l|l|l|l|}
\hline Dependent Mean & 3.88693 & R-squared & 0.8490 \\
\hline Coefficient Variance & 8.76191 & Adjusted R-squared & 0.8449 \\
\hline F-Value & 206.24 & Pr>F & $<.0001$ \\
\hline
\end{tabular}

The value of $R^{2}$ of all six factors is presented in Table 6 with a value of 0.8490 . This signifies that all the 6 barriers could significantly account for $84.9 \%$ of the variation in adoption intention and the remaining deviation is comprised of other variables that are not included in this research. The differences among means are significant as long as the calculated F-value is greater than the value in F-table [13]. The F-value as shown in Table 6 is 206.24 with the significance level of <.0001 while the value obtained from the $F$ table is 2.175 . This indicates that the $F$-value is large and the model employed fits this research. Furthermore, $p$-value is less than 0.05 . This shows that at least one of the six independent variables can be used to explain and model the dependent variable. As a conclusion, the relationship between all barriers and adoption intention in this study is significant.

Table 7 gives the parameter estimates for the multiple linear regression.

Table 7: Multiple Linear regression: Parameter estimates

\begin{tabular}{|l|l|l|l|l|l|l|}
\hline Variables & $\begin{array}{l}\text { Parameter } \\
\text { Estimate }\end{array}$ & $\begin{array}{l}\text { Standardized } \\
\text { Estimate }\end{array}$ & t-value & Pr > It $\mid$ & Tolerance & $\begin{array}{l}\text { Variance } \\
\text { Inflation }\end{array}$ \\
\hline Intercept & 6.17507 & 0 & 56.43 & $<.0001$ & - & 0 \\
\hline UB & -0.10816 & -0.11390 & -2.11 & 0.0362 & 0.23488 & 4.25747 \\
\hline VB & -0.14751 & -0.14722 & -2.59 & 0.0101 & 0.21309 & 4.69276 \\
\hline RB & -0.18242 & -0.17564 & -2.43 & 0.0161 & 0.13091 & 7.63902 \\
\hline TB & -0.38393 & -0.33203 & -4.89 & $<.0001$ & 0.14865 & 6.72701 \\
\hline IB & -0.19898 & -0.19550 & -3.31 & 0.0011 & 0.19550 & 5.09896 \\
\hline PCB & -0.02805 & -0.01899 & -0.33 & 0.7427 & 0.20545 & 4.86737 \\
\hline
\end{tabular}

According to Table 7, Usage Barrier (UB) ( $p=0.0362)$, Value Barrier (VB) $(p=0.0101)$, Risk Barrier (RB) $(p=0.0161)$, Tradition Barrier (TB) $(p=<.0001)$ and Image Barrier (IB) $(p=0.0011)$ have a significant relationship with adoption intention of mobile commerce. Tradition barrier has the greatest impact to influence the adoption intention of mobile commerce among these barriers. Nevertheless, perceived cost barrier has no relationship with adoption intention since its $\mathrm{p}$-value is more than 0.05 . As a result, the equation for the model is formulated as follows: $\mathrm{Al}=6.17507$ 0.10816 (UB) -0.14751 (VB) -0.18242 (RB) -0.38393 (TB) -0.19898 (IB) -0.02805 (PCB). Hair et al. [15] recommend that a very small tolerance value ( 0.10 or below) or a large VIF value (10 or above) indicates high collinearity. The results in Table 7 shows the minimum tolerance value of 0.13091 and maximum variance inflation factor of 7.63902 . So there is no problem of multicollinearity in this study.

Then to examine the statistical differences in the mobile commerce adoption intention between the mobile commerce users and non-users, Independent-Samples T test has been conducted. The results are shown in Table 8 and Table 9.

Table 8: Group statistics

\begin{tabular}{|l|l|l|l|l|l|}
\hline & User & $\mathbf{N}$ & Mean & Std. Deavition & Std. Error Mean \\
\hline \multirow{2}{*}{ AlAvg } & User & 146 & 3.9041 & 1.09121 & .09031 \\
\cline { 2 - 6 } & non-user & 81 & 3.8642 & 1.00937 & .11215 \\
\hline
\end{tabular}

Table 9: Independent Samples Test

\begin{tabular}{|c|c|c|c|c|c|c|c|c|c|c|}
\hline & \multicolumn{2}{|c|}{$\begin{array}{l}\text { Levene's Test for } \\
\text { Equality of } \\
\text { Variances }\end{array}$} & \multicolumn{7}{|c|}{ t-test for Equality of Means } \\
\hline & & \multirow[b]{2}{*}{$F$} & \multirow[b]{2}{*}{ Sig. } & \multirow[b]{2}{*}{$t$} & \multirow[b]{2}{*}{$\mathrm{df}$} & \multirow{2}{*}{$\begin{array}{l}\text { Sig. (2- } \\
\text { tailed) }\end{array}$} & \multirow{2}{*}{$\begin{array}{l}\text { Mean } \\
\text { Difference }\end{array}$} & \multirow{2}{*}{$\begin{array}{l}\text { Std. Error } \\
\text { Difference }\end{array}$} & \multicolumn{2}{|c|}{$\begin{array}{l}95 \% \text { Confidence } \\
\text { Interval of the } \\
\text { Difference }\end{array}$} \\
\hline & & & & & & & & & Lower & Upper \\
\hline \multirow[t]{2}{*}{ AlAvg } & $\begin{array}{l}\text { Equal } \\
\text { variances } \\
\text { assumed }\end{array}$ & .379 & .539 & .271 & 225 & .787 & .03991 & .14725 & -.25026 & .33008 \\
\hline & $\begin{array}{l}\text { Equal } \\
\text { variances not } \\
\text { assumed }\end{array}$ & & & .277 & 176.450 & .782 & .03991 & .14399 & -.24426 & .32408 \\
\hline
\end{tabular}

The results show that there is no difference ( $p$ value $>0.05$ ) between the mobile commerce users and non-users in the adoption intention. 


\section{Discussion}

Respondents of our study mostly constitute females with $53.74 \%$. Most of our respondents are Chinese, aged from 50 to 55 and most of them are married. Most of the respondents' highest educational level is high school. The monthly income of the respondents ranges from Ringgit Malaysia (RM) 1,001 - RM3,000. $64.32 \%$ of the total respondents are the users of $\mathrm{m}$-commerce.

Table 10 gives the summary of inferential analysis.

Table 10: Summary table of inferential analysis

\begin{tabular}{|l|l|l|l|}
\hline Variables & Hypotheses & P-value & Supported or Not Supported \\
\hline UB & H1 & 0.0362 & Supported \\
\hline VB & $\mathrm{H} 2$ & 0.0101 & Supported \\
\hline RB & $\mathrm{H} 3$ & 0.0161 & Supported \\
\hline TB & $\mathrm{H} 4$ & $<.0001$ & Supported \\
\hline IB & $\mathrm{H} 5$ & 0.0011 & Supported \\
\hline PCB & $\mathrm{H} 6$ & 0.7427 & Not Supported \\
\hline
\end{tabular}

\subsection{Usage Barrier and Adoption Intention of M-Commerce}

This barrier has a negative relationship and significantly affects the adoption intention of m-commerce of generation $X$ in Malaysia. The greater the usage barrier, the lower is the adoption intention of $\mathrm{m}$-commerce. This result is supported by the studies of Rahman [36] and Mahatanankoon and Vila-Ruiz [28]. According to Rahman [36], the main reason for the existence of this barrier is due to the literacy level of users, which limit them to secure their confidential information of account in mobile when conducting transactions. The highest educational level of over $50 \%$ of our target respondents are high school. They might face confusion towards the usage and progress of transaction using mobile phones to make payment. Another factor is due to the inefficiency of device [28]. The requirement to make in navigation with mobile phone for every extra input reduces $50 \%$ of transaction through mobile.

\subsection{Value Barrier and Adoption Intention of M-Commerce}

Value barrier achieves a p-value of 0.0101 which means that it has got a significant relationship with adoption intention of m-commerce. Our result agrees with previous researches by Mimoun et al. [31], Verkasalo et al. [43] and Roostika [40] which stated that perceived value and adoption intention has a positive relationship. In other words, barrier in value has a negative relationship with the adoption intention. According to Ram and Sheth [37], the reason consumers resist to embrace innovations is because it does not provide them a strong performance-to-price value. Generation X in Malaysia do not feel that it is worthwhile for them to switch from purchasing goods and services at physical merchandise to using mobile. Based on the study of Mimoun et al. [31] another reason for the value barrier is because users do not meet the desired experience, such as convenience, during the usage of mobile commerce.

\subsection{Risk Barrier and Adoption Intention of M-Commerce}

This barrier has established a significant negative relationship with adoption intention of m-commerce. It has generated a p-value $<0.05$ which is 0.0161 from our SAS analysis. This is aligned with researches such as Luo et al. [27], Joubert and Belle [16] and Rahman [36] with the statement of significant negative influence between adoption intention and perceived risk. Performance risk arises from the feeling of uncertainty about an innovation on their reliability [37]. The mobile users might get worried that their private and confidential information will leak by using mobile commerce. According to Luo et al. [27] the existence of risk barrier is due to the lack of education platform to raise the awareness of consumers regarding the security issues of newly implemented technologies.

\subsection{Tradition Barrier and Adoption Intention of M-Commerce}

Tradition barrier is proved to be a significant variable that influences adoption intention of $\mathrm{m}$-commerce. It fulfilled the requirement of $p$-value $<0.05$ with the coefficient of $<.0001$. It is also the most significant factor that affects adoption intention because it has the lowest $p$-value in contrast with other variables. The findings of this research are aligned with Lian and Yen [22] and Laukkanen et al. [20] which produced similar results. Traditional barrier is a type of psychological resistance resulting from a cultural change in consumers created by innovation [37]. Our target respondents are generation $X$ aged from 35-55. Their habit of purchasing goods and services through physical merchandise is hard to change. There is a high possibility that it is not socially acceptable for this generation to 
conduct a transaction through a mobile device [37]. Tradition barrier will also occur due to the preference of customers to shop with the assistance provided by sales staff rather than shopping online [22].

\subsection{Image Barrier and Adoption Intention of M-Commerce}

This variable satisfies the condition of $p$-value less than 0.05 which is 0.0011 . Thus, a significant negative relationship between image barrier and adoption intention of $\mathrm{m}$-commerce is recognized. The outcomes of the researches conducted by Elbadrawy and Aziz [11], Kleijnen et al. [17] and Luakkanen et al. [20] have achieved the same results as this study, which state that image barrier is one of the factors that causes rejection of adoption of technology or innovation by users. Image barrier implies that a negative impression is created due to the perception of complication of the use of the product. The result of this study indicates that most of the generation $\mathrm{X}$ in Selangor and Negeri Sembilan States are facing difficulties in using the mobile device to conduct transactions. According to Lian et al. [21] image barrier exists when customers have a bad experience and impression in using online services previously.

\subsection{Perceived Cost Barrier and Adoption Intention of M-Commerce}

Perceived cost barrier is not supported in this study due to its $p$-value of 0.7427 . It has not fulfilled the requirement of $\mathrm{p}$-value $<0.05$ which signifies that perceived cost barrier has no significant relationship with adoption intention of $\mathrm{m}$ commerce. This is inconsistent with past studies carried out by Yu [47], Lu et al. [25] and Sripalawat et al. [42] which concluded that perceived cost barrier is a factor that hinders users' mobile services adoption. However, this research aligns with the research by Ramlugun and Issuree [38], which indicated that perceived cost barrier has no influence on the intention to adopt mobile related services. One of the possible reasons to explain this is the cost of adoption of mobile commerce is very low [38]. Moreover, the majority of our target respondents are aged from 50-55. Most of them have savings and financial ability. Therefore, perceived cost is not a significant barrier for them to adopt $\mathrm{m}$ commerce. The findings of this study are also supported by Yang, Lu, Gupta, Cao, and Zhang [46] who stated that the cost to adopt $\mathrm{m}$-commerce is reduced very much as compared to early stages and it would not be a primary consideration for consumers as they can evaluate more clearly other positive perceptions. Moreover, the corporates can manage and control their expenses on mobile services as the cost is only a small portion out of their earnings [25]. Yu [47] also states that perceived cost is irrelevant to those who aged above 50. The majority of our target respondents are within the range of 50-55.

\section{Implications}

This study is beneficial and significant to those business practitioners who carry out their daily business transaction through online via mobile device as this research presented a clear vision on factors that affect consumers' adoption intention to use M-commerce to carry out daily business transaction. Most of the past studies were just concerned with the reasons that influence consumers' behavioral intention to adopt M-commerce in foreign countries. This study is carried out to study how Generation X in Malaysia intend to use M-commerce as affected by usage barrier, value barrier, risk barrier, tradition barrier, image barrier and perceived cost barrier. The information and results gathered in this study offer a clearer understanding on those barriers that affect M-commerce adoption in Malaysia especially for Generation X. This study would enable any future researchers who wish to conduct their studies in this area to have a basic idea and serve as a guideline for them and Malaysian citizens as it clearly lists out barriers that influence consumers' behavioral intention to use M-commerce.

Based on data generated from this research, the values of $R^{2}$ of all six factors have a value of 0.8490 . This indicates that all the 6 barriers could significantly account for $84.9 \%$ of the variation in adoption intention. Here, it can be assumed that the remaining deviations are caused by other variables that were not included in this research. This study enables all future researchers to understand more about the factors that affect adoption intention towards mobile commerce. With this study, they will have an idea on which factors should be considered or take more effort by including more factors that may affect the adoption intention. As shown in the result part, usage barrier, values barrier, risk barrier, tradition barrier and image barrier have significant influence towards the adoption intention of $\mathrm{M}$ commerce among these barriers. The majority of the respondents commended that tradition barrier significantly influences their intention to adopt $\mathrm{M}$-commerce. Mobile commerce is not easy to use as it required some procedures before confirming any transaction and create inconvenience due to the network coverage in Malaysia. By referring this study, technology developers can have an idea of simplifying the procedure for any transaction or providing a quick tutorial for the whole transaction and including more language options for all users to overcome the barriers of adoption intention towards M-commerce in Malaysia.

According to the result, tradition barrier is perceived to have the greatest impact on the adoption intention of $\mathrm{M}$ commerce. Tradition barrier occurs when an innovation in technology field poses a change in customers' established tradition [37]. This barrier occurs because users prefer to use their original methods or steps for any transactions and refuse to try using a mobile device to carry out the transaction. Hence, this study enables technology developers to know which barrier affects the most on mobile commerce adoption in Malaysia which in turn allows problem solving to minimize the tradition barrier towards M-commerce. In contrast, perceived cost barrier is insignificant in explaining 
the adoption intention to use M-commerce among generation X in Malaysia. So this factor should no longer be taken into account for any other future researchers who conduct related studies and technology developers who try to improve users' adoption intention towards M-commerce.

Theoretically, this research figures out how important is the Innovation Resistance Theory (IRT) in explaining the barriers against M-commerce adoption intention among Generation X in Malaysia. The adopted conceptual framework centralized on how the six barriers which are usage, value, risk, tradition, image and perceived cost affect M-commerce adoption. Apparently, Innovation Resistance Theory is one of the potential and effective theories employed to understand the barriers against M-commerce adoption among Generation X in Malaysia. In conclusion, Innovation Resistance Theory is one of the most suitable theories that can be considered by any future researchers who would conduct research relating to technological innovation.

\section{Limitations and Recommendations}

This research has addressed several limitations. Firstly, questionnaire survey has been used in this research to collect the information due to its cost efficiency. However, questionnaire survey is not a good way as it is timeconsuming to collect back those questionnaires and possibly unable to collect back the exact amount of questionnaires that were distributed. In order to get more accurate and reliable information, a Face-to-Face interview should be conducted. This method has a characteristic of synchronous communication in time and place. It allows interviewers to take advantage of social or non-verbal cues to gain additional information from the interview. Besides, it enables the interviewee to respond instantly and ensure the answer responded by interviewees are more spontaneous as no time delay between the question and answer. In addition, a cross-sectional study was used to focus on the barriers to mobile commerce adoption among generation $\mathrm{X}$ in Malaysia only for a certain period. It only occurred and focused on a phenomenon during a particular time [41]. It can be irrelevant in the future as this information obtained only reflected that time situation in Malaysia. The finding may get outdated as the time pass. Longitudinal approach is highly recommended as researchers can look at a longer period of time instead of just focusing a particular time frame. Information regarding individuals' change can be provided with more detail by longitudinal data.

Besides, the target respondents in this research are generation $X$ especially from Selangor (Kuala Lumpur) and Negeri Sembilan States. These two States have been chosen due to their highest number of mobile phone users among Malaysians, based on the information available from the Department of Statistics, Malaysia in 2013. It is recommended to include other States also instead of just focusing on few States. This is because different States will have different respondents whereby different responses will be collected with different results generated.

\section{Conclusion}

In brief, this study provided the solution to all research questions and objectives. The relationships between variables are proved to be statistically significant. The findings obtained in this study indicate that usage barrier, value barrier, risk barrier, tradition barrier and image barrier significantly influence the mobile commerce adoption by Generation $\mathrm{X}$ in Malaysia. However, perceived cost barrier does not have an influence on the mobile commerce adoption. This study also concludes that tradition barrier is perceived to have the greatest impact to influence the adoption intention of mobile commerce among those barriers. This study also determines that there is no difference between the mobile commerce users and non-users in the adoption intention among the Generation X in Malaysia. This research also provides an extended Innovation Resistance Theory model with an additional construct, the perceived cost barrier, a negative valence factor, for the adoption intention of mobile commerce.

\section{References}

[1] E. Agwu, From reluctance to resistance: Study of internet banking services adoption in the United Kingdom, Journal of Internet Banking and Commerce, vol. 18, no. 3, pp. 1-18, 2013.

[2] H. D. Aslam, M. Khan, A. Tanveer, and T. Amber, Perceived barriers towards adoption of internet banking among non-metropolitan internet users of Pakistan, International Business \& Economics Research Journal, vol. 10, no. 4, pp. 45-56, 2011.

[3] W. Bakhit, Consumers resistance to eco-innovations, in Proceedings International Conference on Economics, Management and Development, pp. 162-166, 2014

[4] S. Barati and S. Mohammadi, An efficient model to improve customer acceptance of mobile banking, in Proceedings World Congress on Engineering and Computer Science Vol II, pp. 1-5, 2009.

[5] E. Bigné, C. Ruiz and S. Sanz, Key drivers of mobile commerce adoption, an exploratory study of spanish mobile users, Journal of Theoretical and Applied Electronic Commerce Research, vol. 2, no. 2, pp. 48-60, 2007.

[6] S. Cheng, S. J. Lee and K. R. Lee, User resistance of mobile banking in China: Focus on perceived risk, International Journal of Security and Its Applications, vol. 8, no. 2, pp. 167-172, 2014.

[7] M. Claudy, An empirical investigation of consumer resistance to green product innovation, Ph.D. dissertation, Dublin Institute of Technology, Dublin 2011. 
[8] L. J. Cronbach, and R. J. Shavelson, My Current Thoughts on Coefficient Alpha and Successor Procedures, Educational and Psychological Measurement, vol. 64, no. 3, pp. 391-418, 2004

[9] Department of Statistics Malaysia. (2015, February) ICT Use and access by individuals and households survey. Departament of Statistics Malysia, Official Portal [Online]. Available: http://www.statistics.gov.my/index.php? $r=$ home/index\&menu id=b2ROaWpITmQ5NnAvMHVmRjRkZzIBQT09

[10] Digital Malaysia. (2015, February) Digital Malaysia progress report 2012. MDEC. [Online]. Available: http://www.mscmalaysia.my/sites/default/files/pdf/downloads/MSC\%20Malaysia\%20Annual\%20Industry\%20Re port\%202012 compressed.pdf

[11] R. Elbadrawy and R. A. Aziz, Resistance to mobile banking adoption in Egypt: A cultural perspective, International Journal of Managing Information Technology, vol. 3, no.4, pp. 9-21, 2011

[12] D. E. Farrar and R. R. Clauber, Multicolinearity in regression analysis: The problem revisited, The Review of Economics and Statistics, vol. 49 no. 1, pp. 92-107, 2005.

[13] A. Field. (2008) Repeated measures ANOVA using SPSS. Research Methods in Psychology. [Online]. Available: http://www.pc.rhul.ac.uk/staff/j.larsson/teaching/pdfs/repeatedmeasures.pdf

[14] S. Gurtner, Modelling consumer resistance to mobile health applications, in Proceedings Twenty Second European Conference on Information Systems, Israel, 2014, pp. 1-16.

[15] J. F. Hair, B. Black, B. Babin, R. E. Anderson, and R. L. Tatham, Multivariate Data Analysis, 7th Edition. Harlow: Pearson, 2013.

[16] J. Joubert and J. P. V. Belle, The role of trust and risk in mobile commerce adoption within South Africa, International Journal of Business, Humanities and Technology, vol. 3, no. 2, pp. 27-38, 2013.

[17] M. Kleijnen, N. Lee and M. Wetzels, An exploration of consumer resistance to innovation and its antecedents, Journal of Economic Psychology, vol. 30, no. 3, pp. 344-357, 2009.

[18] T. Kuisma, T. Laukkanen and M. Hiltunen, Mapping the reasons for resistance to Internet banking: A meansend approach, International Journal of Information Management, vol. 27, no. 2, pp. 75-85, 2007.

[19] K. Laukkanen and V. Kiviniemi, The role of information in mobile banking resistance, International Journal of Bank Marketing, vol. 28, no. 5, pp. 372-388, 2010.

[20] T. Laukkanen, S. Sinkkonen, M. Kivijarvi, and P. Laukkanen, Segmenting bank customers by resistance to mobile banking, in Proceedings International Conference on the Management of Mobile Business, Toronto, 2007, pp. 1-7.

[21] J. W. Lian, H. M. Liu and I. L. Liu, Applying innovation resistance theory to understand user acceptance of online shopping: The moderating effect of different product types, Computer Technology and Application, vol. 3 no. 2, pp. 188-193, 2012

[22] J. W. Lian and D. C. Yen, To buy or not to buy experience goods online: Perspective of innovation adoption barriers, Computers in Human Behavior, vol. 29, no. 3, pp. 665-672, 2013

[23] F. Liébana-Cabanillas, J. Sánchez-Fernández and F. Muñoz-Leiva, Antecedents of the adoption of the new mobile payment systems: The moderating effect of age, Computers in Human Behavior, vol. 35, no. 1, pp. 464478, 2014

[24] F. J. Lin, Solving multicollinearity in the process of fitting regression model using the nested estimate procedure, Quality \& Quantity, vol. 42, no. 3, pp. 417- 426, 2006.

[25] Y. Lu, S. Yang, P. Y. K. Chau, and Y. Cao, Dynamics between the trust transfer process and intention to use mobile payment services: A cross-environment perspective, Information \& Management, vol. 48, no. 8, pp. 393403, 2011.

[26] P. Luarn and H. H.Lin, Toward an understanding of the behavioral intention to use mobile banking, Computers in Human Behavior, vol. 21, no. 6, pp. 873-891, 2005.

[27] X. Luo, H. Li, J. Zhang, and J.P. Shim, Examining multi-dimensional trust and multi-faceted risk in initial acceptance of emerging technologies: An empirical study of mobile banking services, Decision Support Systems, vol. 49, no. 2, pp. 222-234, 2010.

[28] P. Mahatanankoon and J. Vila-Ruiz, Why won"t consumers adopt m-commerce? An exploratory study, Journal of Internet Commerce, vol. 6, no. 4, pp. 113-128, 2007

[29] Malaysian Communications and Multimedia Commission. (2015, february) Hand phone users survey 2013. MCMC. [Online]. Available: http://www.skmm.gov.my/skmmgovmy/media/General/pdf/SKMM-HANDPHONESURVEY-2011.pdf.

[30] K. Marett, A. W. Pearson, R. A. Pearson, and E. Bergiel, Using mobile devices in a high risk context: The role of risk and trust in an exploratory study in Afghanistan, Technology in Society, vol.41, no. 1, pp. 54-64, 2015.

[31] M. S. B. Mimoun, A. A. Bailey and H. Sassi, Understanding mobile internet adoption by Tunisian consumers: Extending the technology acceptance model, in Proceedings AMA Winter Educators' Conference, Las Vegas, 2013, 394-403.

[32] S. B. Mohtar, M. Abbas and M. N. Baig, A conceptual investigation of consumer resistance to innovation, Middle-East Journal of Scientific Research, vol. 23, no. 2, pp.339-346, 2015.

[33] J. Munusamy, S. Annamalah and S. Chelliah, Perceived barriers of innovative banking among Malaysian retail banking customers, Journal of Internet Banking and Commerce, vol. 17, no. 1, pp. 1-15, 2012.

[34] H. Peng, X. Xu and W. Liu, Drivers and barriers in the acceptance of mobile payment in China, Communication in Information Science and Management Engineering, vol. 1, no. 5, pp. 73-78, 2011.

[35] T. T. Pham and J. C. Ho, The effects of product-related, personal-related factors and attractiveness of alternatives on consumer adoption of NFC-based mobile payments, Technology in Society, vol. 43, no.3, pp. $159-172,2015$ 
[36] M. M. Rahman, Barriers to m-commerce adoption in developing countries- a qualitative study among the stakeholders of bangladesh, The International Technology Management Review, vol. 3, no. 2, pp. 80-91, 2013.

[37] S. Ram and J. N. Sheth, Consumer resistance to innovations: The marketing problem and its solutions, The Journal of Consumer Marketing, vol. 6, no. 2, pp. 5-14, 1989.

[38] V. G. Ramlugun and H. Issuree, Factors determining mobile banking adoption in Mauritius, International Journal of Innovation Research \& Development, vol. 3, no. 1, pp. 193-202, 2014.

[39] N. Rammile and J. Nel, Understanding resistance to cell phone banking adoption through the application of the technology acceptance model (TAM), Journal of Business Management, vol. 6, no. 1, pp.86-97, 2012.

[40] R. Roostika, Mobile internet acceptance among university students: A value-based adoption model, International Journal of Research in Management \& Technology, vol. 2, no. 1, pp. 21-28, 2012

[41] M. Saunders, P. Lewis and A. Thornhill, Research methods for business students (5th ed.). Harlow, England: Prentice Hall, 2009.

[42] J. Sripalawat, M. Thongmak and A. Ngramyarn, M-banking in metropolitan Bangkok and a comparison with other countries, Journal of Computer Information Systems, vol. 51, no. 3, pp. 67-76, 2011

[43] H. Verkasalo, C. López-Nicolás, F. J. Molina-Castillo, and H. Bouwman, Analysis of users and non-users of smartphone applications, Telematics and Informatics, vol. 27 no. 3, pp. 242-255, 2010.

[44] N. M. Webb, R. J. Shavelson and E. H.Haertel, Reliability coefficients and generalizability theory, Handbook of Statistics, vol. 26, no. 1, pp. 4-44, 2006.

[45] T. T. Wei, G. Marthandan, A. Y. L. Chong, K. B. Ooi, and S. Arumugam, What drives Malaysian m-commerce adoption? An empirical analysis, Industrial Management \& Data Systems, vol. 109, no. 3, pp. 370-388, 2009.

[46] S. Yang, Y. Lu, S. Gupta, Y. Cao, and R. Zhang, Mobile payment services adoption across time: An empirical study of the effects of behavioral beliefs, social influences, and personal traits, Computers in Human Behavior, vol. 28, no. 1, pp. 129-142, 2012

[47] C. S. Yu, Factors affectting individuals to adopt mobile banking: Empirical evidence from the UTAUT model, Journal of Electronic Commerce Research, vol. 13, no. 2, pp. 104-121, 2012.

[48] C. S. Yu and C. K. Li, Analysis of consumer e-lifestyles and their effects on consumer resistance to using mobile banking: Empirical surveys in Thailand and Taiwan, International Journal of Business and Information, vol. 10, no. 2, pp. 198-232, 2015. 


\section{Appendix A: Barriers of Mobile Commerce Adoption Intention - Perceptions of Generation X in Malaysia}

\section{Survey Questionnaire}

The purpose of this survey is to conduct a research to investigate the relationship between types of barriers and adoption intention among generation $X$ in Malaysia. Please answer all questions correctly. All responses are completely confidential.

Thanks you for your participation.

Instructions:

1) There are THREE (3) sections in this questionnaire. Please answer ALL questions in ALL sections.

2) Completion of this form will take you less than 5 minutes.

3) The contents of this questionnaire will be kept strictly confidential.

\section{Demographic Profile}

In this section, we would like you to fill in some of your personal details. Please tick your answer and your answers will be kept strictly confidential.

QA 1: Gender:

$$
\begin{aligned}
& \square \text { Female } \\
& \square \text { Male }
\end{aligned}
$$

QA 2: Age:

$$
\begin{aligned}
& \square 35-39 \\
& \square 40-44 \\
& \square 45-49 \\
& \square 50-55
\end{aligned}
$$

QA 3: Marital status:

$$
\begin{aligned}
& \square \text { Single } \\
& \square \text { Married }
\end{aligned}
$$

QA 4: Highest education completed:

$$
\begin{aligned}
& \square \text { High School } \\
& \square \text { Diploma } \\
& \square \text { Degree } \\
& \square \text { Master and above }
\end{aligned}
$$

QA 5: Race:
$\square$ Malay
$\square$ Chinese
$\square$ Indian

QA 6: Income Level:
$\square$ RM 1,000 or below
$\square$ RM 1,001 - RM 3,000
$\square$ RM 3,001 - RM 5,000
$\square$ Above RM 5,000

QA 7: Mobile commerce:
$\square$ User
$\square$ Non-user 


\section{Barriers in Mobile Commerce Adoption Intention}

This section is seeking your opinion regarding the importance of different types of barriers. Respondents are asked to indicate the extent to which they agreed or disagreed with each statement using 5 Likert scale $[(1)=$ strongly agree; $(2)$ = agree; $(3)$ = neutral; $(4)=$ disagree and $(5)=$ strongly disagree] response framework. Please circle one number per line to indicate the extent to which you agree or disagree with the following statements.

\begin{tabular}{|c|c|c|c|c|c|c|}
\hline No & Questions & 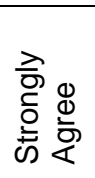 & 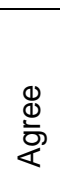 & 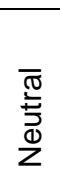 & 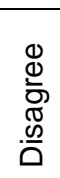 & 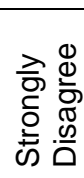 \\
\hline UB & \multicolumn{6}{|l|}{ Usage Barrier } \\
\hline UB1 & $\begin{array}{l}\text { In my opinion, mobile commerce services are difficult to } \\
\text { use. }\end{array}$ & 1 & 2 & 3 & 4 & 5 \\
\hline UB2 & $\begin{array}{l}\text { In my opinion, mobile commerce services are inconvenient } \\
\text { to use }\end{array}$ & 1 & 2 & 3 & 4 & 5 \\
\hline UB3 & In my opinion, mobile commerce services are slow to use. & 1 & 2 & 3 & 4 & 5 \\
\hline UB4 & $\begin{array}{l}\text { In my opinion, progress in mobile commerce services is } \\
\text { unclear. }\end{array}$ & 1 & 2 & 3 & 4 & 5 \\
\hline No & Questions & 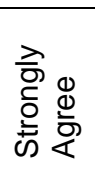 & 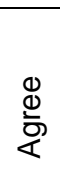 & 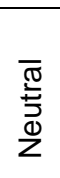 & 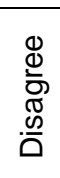 & 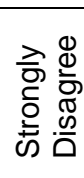 \\
\hline VB & \multicolumn{6}{|l|}{ Value Barrier } \\
\hline VB1 & Using mobile commerce services is uneconomical. & 1 & 2 & 3 & 4 & 5 \\
\hline VB2 & $\begin{array}{l}\text { Using mobile commerce services does not offer any } \\
\text { advantage when compared to other ways of handling } \\
\text { financial matters. }\end{array}$ & 1 & 2 & 3 & 4 & 5 \\
\hline VB3 & $\begin{array}{l}\text { Using mobile commerce services do not increase the } \\
\text { ability to control financial matters. }\end{array}$ & 1 & 2 & 3 & 4 & 5 \\
\hline VB4 & $\begin{array}{l}\text { Using mobile commerce services is not a good substitute } \\
\text { of a PC to conduct transactions. }\end{array}$ & 1 & 2 & 3 & 4 & 5 \\
\hline VB5 & $\begin{array}{l}\text { Using mobile commerce services do not eliminate the } \\
\text { constraints of time and space when conducting } \\
\text { transactions. }\end{array}$ & 1 & 2 & 3 & 4 & 5 \\
\hline No & Questions & 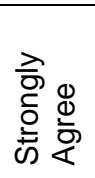 & 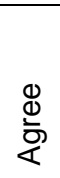 & 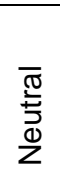 & 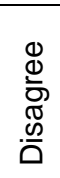 & 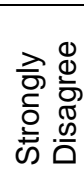 \\
\hline RB & \multicolumn{6}{|l|}{ Risk Barrier } \\
\hline RB1 & $\begin{array}{l}\text { I am afraid for making mistakes in the process of using } \\
\text { mobile commerce. }\end{array}$ & 1 & 2 & 3 & 4 & 5 \\
\hline RB2 & $\begin{array}{l}\text { I am afraid of entering wrong information in the mobile } \\
\text { commerce process. }\end{array}$ & 1 & 2 & 3 & 4 & 5 \\
\hline RB3 & $\begin{array}{l}\text { I am afraid for faultiness in the function of mobile } \\
\text { commerce. }\end{array}$ & 1 & 2 & 3 & 4 & 5 \\
\hline RB4 & $\begin{array}{l}\text { I am afraid for exposure of privacy if using mobile } \\
\text { commerce. }\end{array}$ & 1 & 2 & 3 & 4 & 5 \\
\hline
\end{tabular}




\begin{tabular}{|c|c|c|c|c|c|c|}
\hline \multicolumn{7}{|c|}{ Continued: Table Risk Barrier } \\
\hline RB5 & $\begin{array}{l}\text { I am afraid for unreasonable or fraudulent charges if using } \\
\text { mobile commerce. }\end{array}$ & 1 & 2 & 3 & 4 & 5 \\
\hline No & Questions & 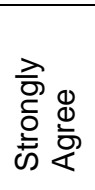 & 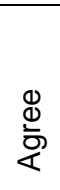 & 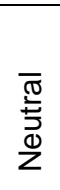 & 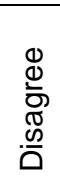 & 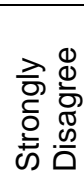 \\
\hline TB & Tradition Barrier & & & & & \\
\hline TB1 & I feel impatient with my m-commerce applications. & 1 & 2 & 3 & 4 & 5 \\
\hline TB2 & I prefers to physical forms of payments. & 1 & 2 & 3 & 4 & 5 \\
\hline TB3 & $\begin{array}{l}\text { I prefer to engage in face-to-face interaction when buying } \\
\text { products or services. }\end{array}$ & 1 & 2 & 3 & 4 & 5 \\
\hline TB4 & I prefer to buy products or services through computers. & 1 & 2 & 3 & 4 & 5 \\
\hline No & Questions & 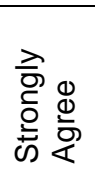 & $\frac{\Phi}{\stackrel{\Phi}{0}}$ & $\begin{array}{l}\overline{\widetilde{\sigma}} \\
\overline{7} \\
\overline{0} \\
Z\end{array}$ & 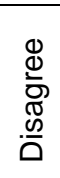 & 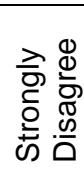 \\
\hline IB & Image Barrier & & & & & \\
\hline IB1 & $\begin{array}{l}\text { Mobile commerce services projected a very negative } \\
\text { image. }\end{array}$ & 1 & 2 & 3 & 4 & 5 \\
\hline IB2 & New technology is often too complicated to use. & 1 & 2 & 3 & 4 & 5 \\
\hline IB3 & $\begin{array}{l}\text { Mobile commerce services are perceived to be difficult to } \\
\text { use. }\end{array}$ & 1 & 2 & 3 & 4 & 5 \\
\hline No & Questions & 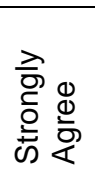 & 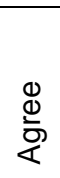 & 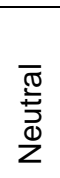 & 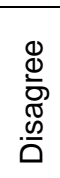 & 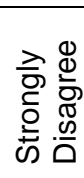 \\
\hline PCB & Perceived Cost Barrier & & & & & \\
\hline PCB1 & I would be charged more to use m-commerce. & 1 & 2 & 3 & 4 & 5 \\
\hline PCB2 & Network connection fees for m-commerce are expensive. & 1 & 2 & 3 & 4 & 5 \\
\hline PCB3 & Extra services charged for m-commerce is expensive. & 1 & 2 & 3 & 4 & 5 \\
\hline PCB4 & M-commerce expenses are burdens for me. & 1 & 2 & 3 & 4 & 5 \\
\hline PCB5 & $\begin{array}{l}\text { Total costs to perform transactions via mobile phone are } \\
\text { more expensive than via other channels. }\end{array}$ & 1 & 2 & 3 & 4 & 5 \\
\hline
\end{tabular}




\section{Mobile Commerce Adoption Intention}

This section is seeking your opinion regarding the impacts of adoption intention of mobile commerce with the types of barriers given. Respondents are asked to indicate the extent to which they agreed or disagreed with each statement using 5 Likert scale [(1) = strongly agree; $(2)$ = agree; $(3)=$ neutral; $(4)=$ disagree and $(5)=$ strongly disagree] response framework. Please circle one number per line to indicate the extent to which you agree or disagree with the following statements.

\begin{tabular}{|c|c|c|c|c|c|c|}
\hline No & Questions & 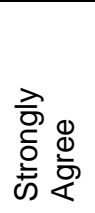 & 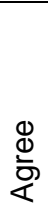 & $\begin{array}{l}\bar{\pi} \\
\frac{\sqrt[0]{5}}{5} \\
\frac{0}{2}\end{array}$ & 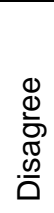 & 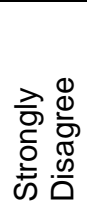 \\
\hline $\mathrm{Al}$ & Adoption Intention & & & & & \\
\hline Al1 & I intend to use mobile commerce. & 1 & 2 & 3 & 4 & 5 \\
\hline $\mathrm{Al2}$ & I intend to use mobile commerce in the future. & 1 & 2 & 3 & 4 & 5 \\
\hline $\mathrm{Al3}$ & $\begin{array}{l}\text { I intend to use mobile commerce in order to increase the } \\
\text { convenience. }\end{array}$ & 1 & 2 & 3 & 4 & 5 \\
\hline Al4 & I intend to learn how to use mobile commerce. & 1 & 2 & 3 & 4 & 5 \\
\hline Al5 & I intend to use mobile commerce more often. & 1 & 2 & 3 & 4 & 5 \\
\hline Al6 & I intend to recommend mobile commerce to my friends. & 1 & 2 & 3 & 4 & 5 \\
\hline
\end{tabular}

